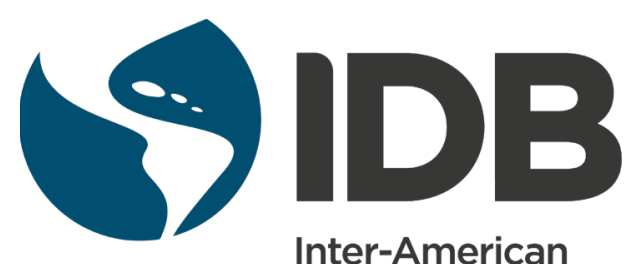

Inter-American

Development Bank

\section{WळRLD ECONOMIC FORUM}

COMMITTED TO

IMPROVING THE STATE OF THE WORLD

\title{
Improving Infrastructure \\ Financing in Brazil
}

In collaboration with the Inter-American Development Bank

\section{January 2019}

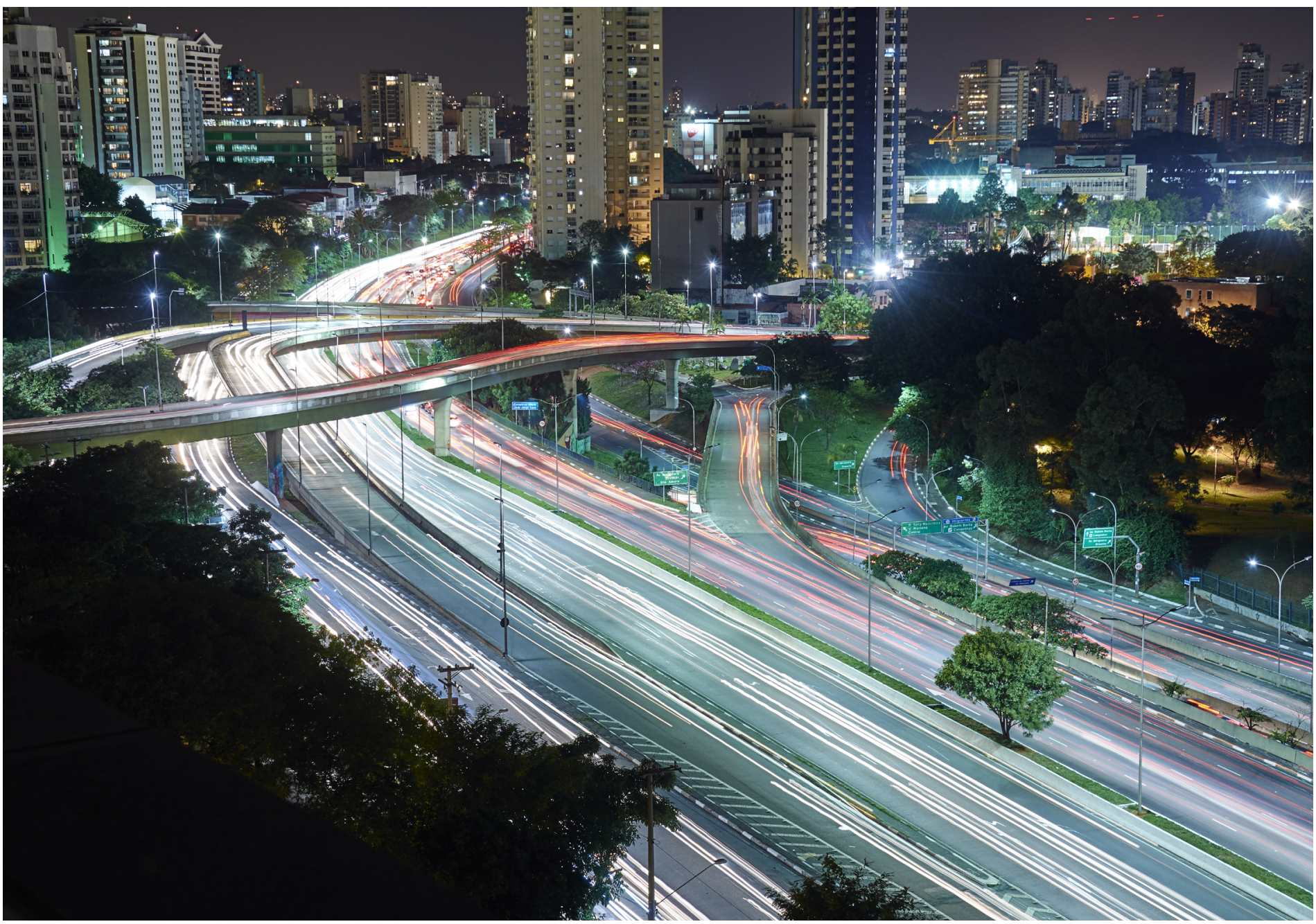


Cataloging-in-Publication data provided by the Inter-American Development Bank

Felipe Herrera Library

World Economic Forum.

Improving infrastructure financing in Brazil /

World Economic Forum, Inter-American Development Bank.

p. cm. - (IDB Monograph ; 694)

Includes bibliographic references.

1. Infrastructure (Economics)-Brazil-Finance.

2. Investments, Foreign-Brazil. I. Inter-American Development Bank. Office of Strategic Planning and Development Effectiveness. II. Title. III. Series.

IDB-MG-694

Keywords: Infrastructure Investment, Private Investment, Public-private partnerships, Brazil

JEL codes: G15, G28, G38, H54, H81, O18, O54

World Economic Forum

91-93 route de la Capite

$\mathrm{CH}-1223$ Cologny/Geneva

Switzerland

Tel.: +41 (0)22 8691212

Fax: +41 (0)22 7862744

Email: contact@weforum.org

www.weforum.org

Copyright (c) 2019 World Economic Forum and Inter-American Development Bank (jointly referred to as the "Co-publishers"). The opinions expressed in this publication are those of the authors and do not necessarily reflect the views of the co-publishers, the IDB Board of Directors, the IDB Board of Governors, or the countries they represent.

This work is licensed under a Creative Commons IGO 3.0 Attribution-NonCommercialNoDerivatives (CC-IGO BY-NC-ND 3.0 IGO) license (https://creativecommons.org/licenses/ by-nc-nd/3.0/igo/legalcode) and may be reproduced with attribution to the Co-publishers and for any non-commercial purpose. No derivative work is allowed. Any dispute related to the use of the works of the Co-publishers that cannot be settled amicably shall be submitted to arbitration pursuant to the UNCITRAL rules. The use of the Co-publishers' names for any purpose other than for attribution and the use of the Co-publishers' logos shall be subject to a separate written license agreement between the Co-publishers and the user, and is not authorized as part of this CCIGO license. Note that link provided above includes additional terms and conditions of the license. 


\section{Contents}

Preface

Foreword $\quad 5$

$\begin{array}{lr}\text { Executive Summary } & 6\end{array}$

$\begin{array}{lr}\text { Changes in the Financing Model } & 8\end{array}$

Current Funding Sources and Forecasts $\quad 9$

The Role of BNDES under the New Model $\quad 11$

$\begin{array}{ll}\text { Recommendations } & 12\end{array}$

1. Crowd in foreign finance by mitigating currency risk 12

2. Mitigate construction risks by enhancing local market instruments $\quad 12$

3. Recycle BNDES assets and further develop capital market instruments by broadening the investor 13 base

4. Reduce the impact of Basel III rules and other restrictions on long-term banking 13

5. Other recommendations 13

Next Steps and Action Plan $\quad 14$

$\begin{array}{ll}\text { Endnotes } & 15\end{array}$

$\begin{array}{ll}\text { References } & 16\end{array}$

$\begin{array}{ll}\text { Acknowledgements } & 17\end{array}$ 


\section{Preface}

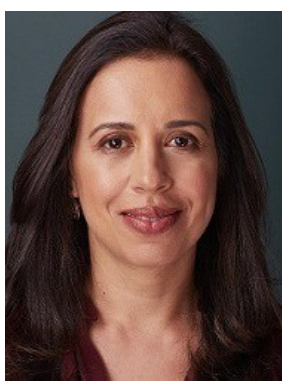

Maha Eltobgy, Head of Investors and Infrastructure, Member of the Executive Committee, World Economic Forum
Many governments are finding it difficult to finance the growing demand for essential infrastructure through public funding alone. With the significant increase of debt in many countries while needs for essential infrastructure continue to expand, private-sector involvement has increasingly been viewed as a potential solution to closing the infrastructure financing gap and ensuring the efficient delivery and operation of infrastructure services. Still, private-sector investment in infrastructure, particularly in developing countries, remains low owing to a variety of real and perceived challenges.

This insight report is the culmination of a multi-year collaboration between the Inter-American Development Bank and the World Economic Forum Global Future Council on Long-Term Investing, Infrastructure and Development 2016-2018. It presents recommendations that incorporate public and private sector input on how to tackle the key challenges in Brazil's infrastructure market. The goal is to enhance trust between the public and private sectors, so that they may jointly mobilize more domestic and international financing to meet Brazil's long-term infrastructure needs and increase the participation of long-term investors in Brazil's infrastructure market.

The recommendations in this report build on those in the World Economic Forum report on Risk Mitigation Instruments in Infrastructure - Gap Assessment (2016), and this body of work has provided valuable insights to the Forum's National Infrastructure Acceleration Initiative. The recommendations herein were developed through the conduct of interviews with working group members from the private sector and were endorsed by selected policy-makers.

We would like to thank the Inter-American Development Bank, the Co-Chairs of the Global Future Council on Long-Term Investing, Infrastructure and Development Rashad R. Kaldany and Alison Tarditi, as well as Global Future Council member Sylvia Coutinho for their executive leadership and support throughout this work, and the interview participants and members of the working group for their invaluable contribution to this work. 


\section{Foreword}

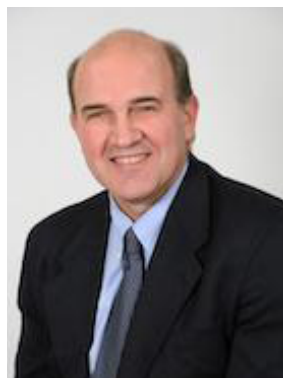

Agustin Aguerre, Manager, Infrastructure and Energy Sector Inter-American Development Bank
Brazil's infrastructure investment as a proportion of GDP is estimated to be around $2 \%$, whereas it is near 7\% in China and 5.5\% in India. This poses a significant challenge to realize Brazil's growth potential. Higher investment in infrastructure would increase export competitiveness and boost productivity growth. Returning Brazil to a sustainable growth path requires scaling up investment in infrastructure to levels at least twice current levels. Political support is key to meeting this challenge. A coordinated effort by all stakeholders from the public sector, market participants and the international community is also essential considering the complex, multidisciplinary and long-term nature of infrastructure investment.

This study presents a set of recommendations for Brazil to transition to a new model of infrastructure financing. The recommendations are the result of extensive informal consultations conducted by experts in project finance with relevant stakeholders in the Brazilian infrastructure sector. This effort was facilitated by a pioneering partnership between the Inter-American Development Bank (IDB) and the World Economic Forum (the Forum). Close to 100 interviews and meetings were held with executives of state-owned and privately-owned banks, construction companies, utility companies, asset management firms and government officials.

The study's main recommendations concern improving the role of the BNDES, Brazil's national development bank, as a private-sector catalyst that mobilizes resources to finance infrastructure projects. While maintaining its essential role in infrastructure financing, the BNDES will have to develop measures to mitigate risks by using project guarantees more extensively and by enlarging the pool of financiers. The recommendations herein echo the international call led by the United Nations, the G20, the G7 and other international fora to enhance the mobilizing role of multilateral development banks (MDBs) by crowding in private resources.

Infrastructure development generally finds broad support across the political spectrum. We hope that this report will provide useful guidance and insights for establishing an infrastructure policy agenda for the coming years. 


\section{Executive Summary}

Brazil is transitioning from a model in which public financing is the dominant source for its infrastructure needs to a more balanced model in which the National Bank for Economic and Social Development (BNDES) will be a catalyst for domestic and foreign private funding. This transition requires fundamental changes in instruments and rules to better manage risks and standardize the processes, contracts, financing instruments and insurance policies related to infrastructure projects and concessions needed to attract institutional investors.

This report presents the opportunities and challenges before the country's infrastructure sector, with a focus on improved use of project guarantees, mitigation of certain risks, and the use of an enlarged pool of financiers.

Since 2014, the financing model for infrastructure projects that had long prevailed in Brazil and depended heavily on concessional BNDES lending, has been challenged by a series of events ranging from corruption scandals to a recession, defaults affecting long-term and bridge loans from banks, and fewer instruments available for covering project risks.

Brazil's infrastructure is currently insufficient to meet the country's development needs after years of underinvestment and requires investment conservatively estimated at around 3.2\% of GDP over 2019-2024. The total investment needed over the period comes to approximately $\mathrm{R} \$ 205$ billion annually. It is estimated that more than half of that must come from private domestic sources. Improving access to private finance implies changing the role of BNDES from a mere financier to a catalyst capable of mobilizing other sources of finance for infrastructure projects. This means that while BNDES will remain essential to financing infrastructure - especially in sectors such as railways, urban mobility, water and sanitation, and social projects - it will also need to "crowd in" other players by mitigating risks, such as completion risk and currency risk. With respect to currency risk, other Latin American countries, such as Chile and Peru, have demonstrated in the field of energy that by providing power purchase agreements (PPA) in US dollars they have been able to access cheaper and longer-term finance, particularly for renewables, which has led to the reduction of costs of generating electricity.
This report presents a series of recommendations intended to address some of the main challenges facing Brazil's infrastructure sector as it transitions to this new financing model.

Key recommendations include:

\section{Crowd in foreign finance by mitigating currency risk}

Three measures to mitigate the risk associated with foreign exchange fluctuations are particularly worth pursuing:

\section{- Encourage the electricity sector to offer certain} power purchase agreements (for instance, for renewables and transmission lines) in US dollars, up to a cap (for example, 10\% of total sector revenues). This will allow concessionaires to access longer-term and cheaper financing in international markets, and ultimately reduce electricity prices for consumers.

- Explore the advantages and disadvantages of using hedging mechanisms such as those recently used for toll roads and airport projects that allow for the risks of funding in foreign currency, limited to a cap, to be offset against the variable grant payments to the government.

- Improve the liquidity of long currency swaps. This market in Brazil is highly liquid only for terms of up to five years. Making longer-term swaps more liquid could serve as an option for projects where the two previous alternatives are neither feasible nor available.

2. Mitigate construction risks by enhancing local market instruments

- Reinforce Brazilian insurers' insurance policy for completion risks, to differentiate it from banking guarantees by requiring the former to cover the physical completion of a project and the latter its financial completion.

- Standardize engineering, procurement and construction (EPC) contracts in infrastructure projects. 
- Develop "Mini-Perm" loans, which are long-term loans that commercial banks extend to a concessionaire, and that allow the bank to execute a PUT option against another lender after the physical and financial completion of the project.

- Enhance project finance through the involvement of multilateral development banks (MDBs), in partnership with BNDES, to partially or fully guarantee infrastructure debentures (a project bond exempt from income tax) during the construction phase.

\section{Recycle BNDES assets and further develop capital} market instruments by broadening the investor base

- BNDES could facilitate the prepayment of debts - currently allowed but difficult to do - so that concessionaires can take long-term loans with BNDES but prepay them by issuing infrastructure debentures. This would also allow BNDES to recycle its capital and support more projects.

Regarding infrastructure debentures:

- Extend the exemption to bonds denominated in Brazilian reals issued abroad, to differentiate, in tax terms, from the jurisdiction in which the bond is issued.

- Shift the tax benefits from the investor to the issuer. This would help level the playing field between foreign investors, pension funds and other investors.

\section{Reduce the impact of Basel III rules and other restrictions on long-term banking}

Capital requirements after Basel III dramatically reduced the capacity of banks to finance large projects in Brazil. To address this issue, this study makes the following recommendation:
- Use capital market financing, not constrained by Basel III regulations, more intensively. Specifically, BNDES operations conducted through commercial banks could be structured as debentures. This would give commercial banks more flexibility to reduce their balance sheets and capital requirements over time.

Responsibilities for improving infrastructure financing in Brazil should be borne by both public and private agents. On the one hand, recommendations related to tax equalization on debentures and bonds, investment fund requirements and Basel III rules can only be led by the government. On the other, standardization of engineering, procurement and construction contracts, insurance policies, step-in clauses, and Mini-Perms should be led by capital market associations, BNDES and major commercial banks. Once private agents start adopting these practices, they are likely to become market standards.

The ultimate goal of these reforms is to improve the coverage, access and quality of infrastructure services for Brazilian citizens and to increase Brazil's long-term growth potential by creating business opportunities in the infrastructure sector. The Inter-American Development Bank and the World Economic Forum, sponsors of the study that serves as the basis of this report, stand ready to support the implementation of these recommendations by the Brazilian government. 


\section{Changes in the Financing Model}

The prevailing financing model for infrastructure projects in Brazil has undergone tremendous change in recent years. The previous model depended heavily on concessional BNDES funding, based on the subsidized Taxa de Juros de Longo Prazo (TJLP), or Long-Term Interest Rate. ${ }^{2}$ Large corporations that could provide real assets or banking guarantees as collateral were the main borrowers. These long-term funds were usually released around two years after the start of projects, which is why commercial banks often provided bridge loans to cover this gap.

Since 2014, many factors have challenged this model. First, an investigation into corrupt practices, the Operação Lava-Jato ("Carwash Operation"), undermined most of the large engineering, procurement and construction companies operating in Brazil. Second, the most serious economic crisis in 80 years led to an $8 \%$ decline in GDP in two years. Third, Basel III regulations and an increase in loan defaults have constricted long-term and bridge loans from commercial banks. Fourth, insurance instruments available to cover construction risks remain scarce, while the costs of banking guarantees for the construction phase have increased. Fifth, the base of lenders remains narrow; only a small number of local banks have balance sheets sufficient to finance large projects (above $\mathrm{R} \$ 1$ billion). The capacity of local capital markets to finance large-scale projects remains limited. Sixth, high yields in safe and liquid financial local currency assets have reduced the attractiveness for infrastructure assets in investor portfolios.
In May 2016, the Brazilian government initiated efforts to further develop infrastructure public-private partnerships (PPPs) and concessions. Besides launching a dedicated unit (known as the PPI Special Secretariat) to better coordinate ministries, regulatory agencies, financiers, and concessionaires, the government took significant steps to increase transparency in concession procurement processes and to improve investor confidence and financing conditions. Among these steps were the gradual elimination of the TJLP and its replacement with a marketreferenced rate Taxa de Longo Prazo (TLP), or Long-Term Rate, the reduction of BNDES support to projects along with an encouragement to use capital market instruments (debentures), and improved alignment of capital expenses with revenues in project cash flows. 


\section{Current Funding Sources and Forecasts}

After the worst recession in 80 years, the Brazilian economy is finally regaining traction in consumer spending and investor confidence. However, the country's current infrastructure is insufficient to meet its development needs after years of underinvestment (around 2.3\% of GDP over 1993-2015). ${ }^{3}$ The pick-up in growth will require a boost in energy and logistics investments that this study estimates could amount to approximately 3.2\% of GDP in 2019$2024,{ }^{4}$ taking into consideration some technical and financial restrictions. This conservative estimate is lower than the 5\% of GDP estimated by other international experts. ${ }^{5}$

Figure 1 illustrates the amounts in Brazilian reals of investment in each infrastructure area since 2012 and the BNDES estimates for 2017-2020, based on client queries for new loans. Table 1 separates out telecommunications from other infrastructure because telecom investments in Brazil are usually made by private companies and financed by corporate debt and equity instead of relying on BNDES support, more readily sought in other infrastructure sectors.

BNDES made massive investments in 2012-2015, peaking at $R \$ 64.3$ billion in 2014. In 2016, this amount declined by one-third ( $\mathrm{R} \$ 23.8$ billion), although the other sources of financing remained at the same levels. According to BNDES estimates for 2017-2020, infrastructure will require around $\mathrm{R} \$ 78$ billion in investment, of which BNDES will fund only $\mathrm{R} \$ 15$ billion. The remaining financing needs will come from a mix of public and private sources. Under this scenario, financing for infrastructure investment is expected to be sufficient in the next few years. ${ }^{6}$
According to the study, it is estimated in 2019-2024 approximately $\mathrm{R} \$ 205$ billion will be invested per year on the assumption that $\mathrm{R} \$ 60$ billion per year (30\%) would be financed via equity, some $R \$ 30$ billion a year would be financed by BNDES and R $\$ 115$ billion by other sources. Most of the other sources will have to come from domestic and foreign capital markets (debentures and infrastructure debentures). Consequently, determining how to improve access to those markets should be a centrepiece of the government's infrastructure policy and is the main objective of this report. The scenario calling for an increase of $R \$ 115$ billion per year assumes that domestic pension funds and asset managers would increase their allocations to infrastructure assets. However, the increase in volumes reflected in the (red boxed) amount in Figure 1 would only be possible by also attracting foreign sources of funding. 
Figure 1: Investment \& Sources of financing

\section{a. Infrastructure investment by sector}

\begin{tabular}{|c|c|c|c|c|c|c|c|}
\hline $\mathrm{R} \$$ billion & & & & & & $\begin{array}{l}\text { BNDES Forecast } \\
\text { (period average) }\end{array}$ & $\begin{array}{l}\text { Author Forecast } \\
\text { (period average) }\end{array}$ \\
\hline & 2012 & 2013 & 2014 & 2015 & 2016 & $2017-2020$ & $2019-2024$ \\
\hline Electric Power & 71,6 & 59,1 & 54,9 & 52,8 & 56,9 & 39,5 & 80,0 \\
\hline Highways & 19,7 & 19,5 & 17,9 & 14,0 & 8,2 & 9,7 & 40,0 \\
\hline Railways & 8,0 & 9,1 & 9,3 & 9,4 & 5,9 & 6,0 & 20,0 \\
\hline Ports & 7,2 & 3,1 & 6,9 & 7,3 & 3,6 & 3,8 & 10,0 \\
\hline Airports & 3,3 & 8,8 & 4,7 & 3,5 & 2,5 & 2,2 & 5,0 \\
\hline Sanitation & 13,0 & 13,2 & 14,3 & 13,0 & 12,4 & 10,4 & 25,0 \\
\hline Solid Waste & 1,2 & 1,4 & 1,4 & 1,2 & 1,2 & 1,4 & 5,0 \\
\hline Urban Mobility & 3,5 & 7,3 & 9,8 & 17,0 & 6,5 & 4,8 & 20,0 \\
\hline Infrastructure - without telecom & 127,5 & 121,5 & 119,2 & 118,2 & 97,2 & 77,8 & 205,0 \\
\hline Telecom & 34,3 & 39,6 & 37,1 & 32,0 & 27,5 & 26,7 & 40,0 \\
\hline Infrastructure - Total & 161,8 & 161,1 & 156,3 & 150,2 & 124,8 & 104,6 & 245,0 \\
\hline$\%$ GDP & $3,1 \%$ & $3,0 \%$ & $2,7 \%$ & $2,5 \%$ & $2,0 \%$ & $1,5 \%$ & $3,2 \%$ \\
\hline
\end{tabular}

Sources: Mellis and Fenolio (2018) based on data from BNDES (2017), SIAFI and ANBIMA.

Note: ANBIMA = Associação Brasileira das Entidades dos Mercados Financeiro e de Capitais; BNDES = Brazilian Development Bank; SIAFI = Sistema Integrado de Administração Financeira do Governo Federal (Integrated System of Federal Government Financial Administration).

\section{b. Sources of infrastructure financing ${ }^{1}$}

\begin{tabular}{|c|c|c|c|c|c|c|c|}
\hline $\mathrm{R} \$$ billion & & & & & & $\begin{array}{l}\text { BNDES Forecast } \\
\text { (period average) }\end{array}$ & $\begin{array}{l}\text { Authors Forecast } \\
\text { (period average) }\end{array}$ \\
\hline & 2012 & 2013 & 2014 & 2015 & 2016 & $2017-2020$ & $2019-2024$ \\
\hline \% equity (estimated) & $34 \%$ & $20 \%$ & $10 \%$ & $23 \%$ & $36 \%$ & $37 \%$ & $29 \%$ \\
\hline$\%$ debt (estimated) & $66 \%$ & $80 \%$ & $90 \%$ & $77 \%$ & $64 \%$ & $63 \%$ & $71 \%$ \\
\hline Infrastructure debt financing & 84,2 & 97,6 & 106,9 & 91,0 & 62,1 & 49,0 & 145,0 \\
\hline \multicolumn{8}{|l|}{ of which: } \\
\hline BNDES disbursements (without telecom) & 48,2 & 60,0 & 64,3 & 52,3 & 23,8 & 15,0 & 30,0 \\
\hline Infrastructure debentures & 2,5 & 4,1 & 5,5 & 5,0 & 4,5 & 5,0 & 20,0 \\
\hline Fl-FGTS & 2,5 & 2,5 & 3,2 & 3,0 & 3,0 & 3,0 & 5,0 \\
\hline CEF & 10,0 & 10,0 & 18,3 & 15,0 & 15,0 & 10,0 & 15,0 \\
\hline Corporate debentures & 4,0 & 4,0 & 6,6 & 6,6 & 6,6 & 4,0 & 40,0 \\
\hline Multilaterals + other DFls & 2,0 & 2,0 & 4,1 & 4,1 & 4,1 & 2,0 & 5,0 \\
\hline Commercial banks + others & 15,0 & 15,0 & 5,0 & 5,0 & 5,0 & 10,0 & 30,0 \\
\hline
\end{tabular}

Sources: Mellis and Fenolio (2018) based on data from BNDES (2017), SIAFI and ANBIMA.

Note: DFls = Development Financial Institutions; FI-FGTS = Fundo de Investimento do Fundo de Garantia por Tempo de Serviço (Investment Fund of the Worker's Severance Guarantee Fund); SIAFI = Sistema Integrado de Administração Financeira do Governo Federal (Integrated System of Federal Government Financial Administration); CEF = Caixa Econômica Federal (federal government-owned savings bank).

${ }^{1}$ Forecast and estimates in grey. 


\section{The Role of BNDES under the New Model}

Figure 2 shows the expansion of the BNDES credit portfolio after 2005 and the decline in recent years. Considering that BNDES took over responsibility for financing most of the large projects in Brazil, the question now is what its next role should be.
Considering the new profile of infrastructure investors and sponsors, as well as the changes in public policies, the role of BNDES must change from a mere financier to an important catalyst that mobilizes private resources to finance infrastructure projects. This means that while BNDES will still remain essential for financing infrastructure, particularly in sectors such as railways, urban mobility, water and sanitation, and social projects, it will also need to play a key role in crowding in other players by mitigating some risks when others cannot afford to.

Figure 2: BNDES Disbursements, 2000-2018 [millions of Brazilian reals]

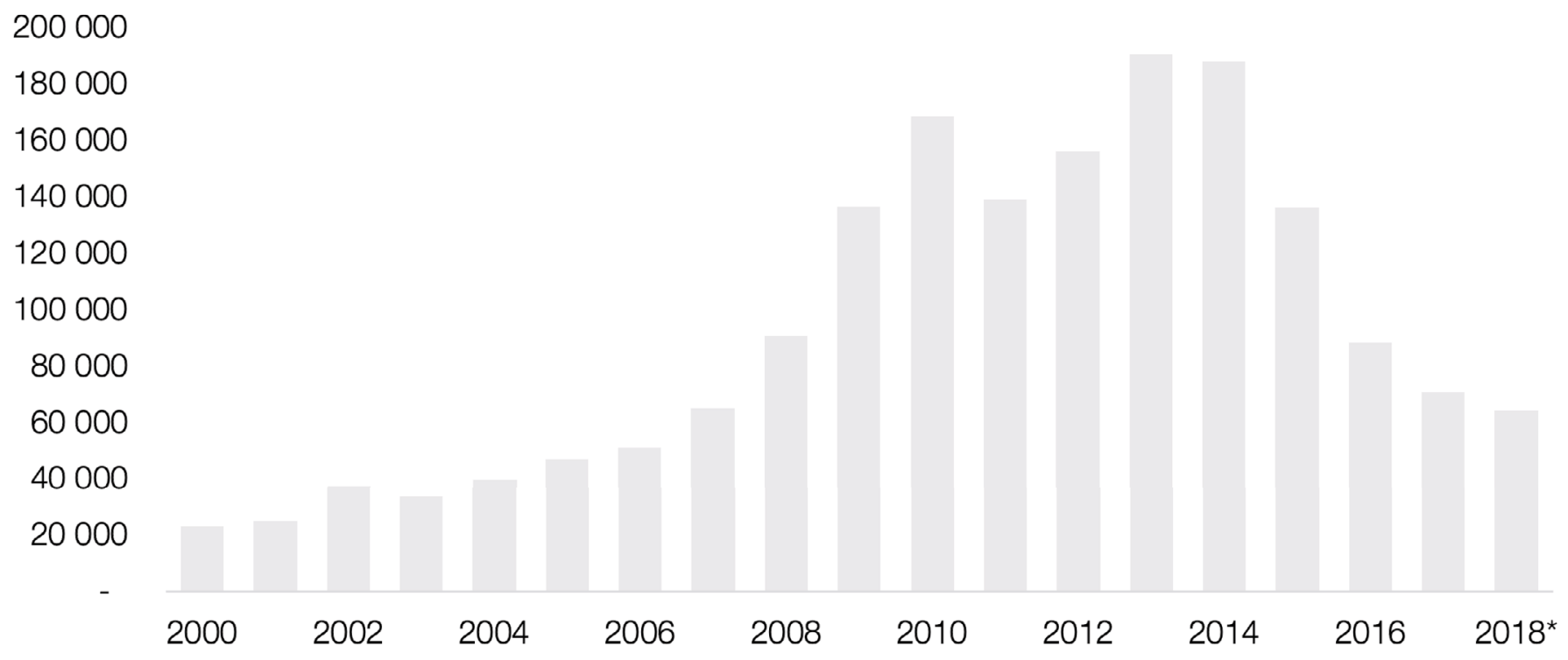

Source: BNDES

* September, last twelve months. 


\section{Recommendations}

\section{Crowd in foreign finance by mitigating currency risk}

The experience of financing infrastructure projects in other Latin American countries such as Chile, Peru, Colombia and Mexico indicates that the provision of revenues in US dollars has allowed for cheaper and longer-term financing, particularly in renewable electricity generation. Time-tomaturity of debentures issued in domestic currency in Brazil's capital market has been relatively short. The average tenure of infrastructure debentures is 9 years, and only 12 out of 186 debenture issuances since 2012 had a tenure of at least 15 years. BNDES is still the almost exclusive source of loans with tenure of 25 years or more. ${ }^{7}$ The reduction in financing expenses reflected in lower yields and higher tenure available in hard currency would ultimately benefit end consumers because it reduces projects costs, resulting in lower user charges.

Financing infrastructure projects in US dollars comes with risks: on the one hand, it raises debt tenure and reduces interest rates; on the other, it adds volatility in debt service costs in local currency. Most infrastructure project revenues are in local currency, and they are not easily hedged. Projects may therefore be subject to severe financial distress in occurrences of unhedged exchange rate volatility.

In Brazil, two complementary solutions could be pursued. First, a portion of infrastructure project revenues could be indexed to US dollars, which would pave the way for tapping more liquid, longer-term and lower-cost international financial markets. Second, foreign exchange rate hedges could be provided through clauses built into concession agreements or through measures to increase the long-term currency swap market liquidity.

The Brazilian Government should examine the possibility of offering power purchase agreements in US dollars, in specific sectors such as transmission lines and renewables, to enable concessionaires to access longer-term and cheaper financing in international markets. This greater leverage in financing could result in greater discounts on the ceiling tariff in auctions, benefiting energy consumers by reducing the initial tariff they pay for services.

Another suggestion is to examine the advantages and disadvantages of using contractual hedging mechanisms in other sectors, such as the one developed for the last airport concession round. This mechanism basically allows for the risks of funding in foreign currency, limited to a cap, to be offset against the variable grant payment.

In addition, measures aimed at improving the liquidity of long-term currency swaps could offer an alternative for projects for which neither of the two previous alternatives work. The swap market in Brazil is highly liquid for terms up to five years, so efforts to increase liquidity in longer terms are needed.

These three measures try to match the currency risk of revenues and debt in a project. They are essential alternatives for crowding in foreign funding to projects, offering large pools of long-term credit for the financing of infrastructure in Brazil.

\section{Mitigate construction risks by enhancing local market instruments}

An insurance policy is available for completion risks in Brazil (Seguro Completion), but it has a spotty history. To reinvigorate the Seguro Completion, it is important to differentiate it from bank guarantees (Fiança Completion) by specifying that the former should cover a project's physical completion and the latter its financial completion. Insurance companies have an interest in relaunching the Seguro Completion but need the step-in clauses to be improved and for an engineering team to monitor the various stages of the project. The Fiança Completion would benefit from thirdparty validation of project completion.

One interesting and simple recommendation is to standardize the engineering, procurement and construction contracts in infrastructure projects by adopting, for instance, International Federation of Consulting Engineers (FIDIC) rulings. This would facilitate assessment by financiers. The same recommendation applies to the adoption of accredited certification of projects that would rate their viability in terms of their technical and financial aspects, and their execution term.

Another important suggestion is to develop "Mini-Perm" loans or long-term loans that commercial banks extend to a concessionaire. These arrangements allow the bank to liquidate the loan against another lender after the physical and financial completion of the project. BNDES could issue a PUT option on these loans to be exercised after completion. For instance, a commercial bank could lend to a project for 15 years and, after completion in year six, the bank could exercise a PUT option against BNDES or keep the loan. This would attract more private loans to infrastructure and reduce the period of BNDES commitment to funding from the period under the current arrangement. Another recommendation to enhance project credit is to involve multilateral development banks (MDBs), in partnership with BNDES, to fully or partially guarantee the issuance of debentures during the construction phase. This could be done by MDBs financing a fund for guaranteeing completion. In any event, the reduction in the interest rate due to credit enhancement should be higher than the cost of an MDB guarantee scheme, resulting in a lower all-in cost for the operation. 


\section{Recycle BNDES assets and further develop capital market instruments by broadening the investor base}

The prepayment of debts is currently allowed, but difficult. BNDES could facilitate prepayment so that concessionaires could take long-term loans with BNDES but prepay them by issuing debentures. This would also allow BNDES to recirculate its capital and consequently support more projects. Another step along those same lines would be for BNDES to step up rates on a loan according to the accrued term.

The infrastructure debenture law exempts those types of debentures from income tax on interest earned when bought by individual, institutional or foreign investors in Brazil. The exemption, however, does not apply to bonds issued abroad by the same infrastructure projects. This study recommends that these bonds should be exempt from withholding tax, so that the project would be indifferent, in tax terms, to the jurisdiction in which the debt instrument is issued. According to investors interviewed in the preparation for this study, there would be a relevant market for bonds in Brazilian reals under New York jurisdiction.

The tax exemption for infrastructure debentures has worked well in attracting high-income individuals to the market. It has failed, however, to attract institutional and foreign investors because they are already exempt in other, less risky assets, such as treasury bonds. The tax benefits of infrastructure debentures could be transferred from the investor to the issuer to enlarge the investor base.

\section{Reduce the impact of Basel III rules and other restrictions on long-term banking}

Capital requirements from commercial banks after the implementation of Basel III in Brazil dramatically reduced their capacity to finance large infrastructure projects. Under the Basel III liquidity framework, banks are required to hold more capital when lending long term in project finance structures. This limits the ability and willingness of commercial banks to engage in such operations due to the higher costs imposed on their balance sheets. Another restriction related to Basel III regulations is the maximum credit exposure to an economic group. If a series of projects will be conducted by the same economic group - each one of them a special-purpose vehicle (SPV) - the first project to be supported by a long-term loan can exhaust the capacity of that bank to support subsequent projects.

In this more restrictive regulatory environment for infrastructure lending by commercial banks, a few alternatives could be considered. First, capital market financing, which is not constrained by Basel III regulations, could be used more intensively. For instance, indirect BNDES operations conducted through commercial banks could be structured as debentures, allowing commercial banks to have more flexibility in reducing their balance sheets and capital requirements over time. Second, if the regulation were to allow the SPV to be independent of the credit of the sponsor, after financial completion, more room for credit would be released to that economic group under maximum credit exposure requirements.

\section{Other recommendations}

One suggestion for reducing the amount of equity required for a project is to replace insurance policies or banking guarantees with reserve accounts. The latter are established in an infrastructure project as a liquidity buffer to match the payments to creditors during periods when cash flow is tight. Nonetheless, they are part of the equity required from shareholders and add equity costs to the project. If they were replaced by other guarantees, this would reduce project costs without reducing guarantees to creditors.

When a project defaults on payments to creditors, the concession agreement and related financial documentation generally have step-in rights provisions, which allow creditors to take over the operation and the assets related to that project. To improve step-in rules, regulations could make clear that, in project finance cases, the initial shareholders should have no right to claim any assets of the concession after the step-in clause enters into effect. 


\section{Next Steps and Action Plan}

Responsibilities for improving infrastructure financing in Brazil should be borne by both public and private agents. Only the government can implement recommendations related to tax equalization on debentures and bonds, investment fund requirements, step-in regulations and Basel III rules. These recommendations could be implemented in the short term, depending on the political context and the fiscal and monetary conditions. On the other hand, market associations, BNDES and major commercial banks should take the lead in standardizing engineering, procurement and construction contracts, insurance policies and Mini-Perms. Once these parties start adopting these practices, they are likely to become market practices.

Certain recommendations depend on changes to BNDES policies and practices, such as the prepayment of debts, stepping up rates on loans to stimulate capital recirculation, on lending with debentures and substituting an insurance instrument for reserve accounts in concessions. Of course, BNDES will need to align some of these changes with other government entities.

When it comes to the recommendations associated with currency risk, "one size does not fit all." They are sector- or project-specific and will require better coordination among various government entities, such as the Ministries of Finance, Planning, Transportation and Energy, the Casa Civil, ${ }^{8}$ and the Special Secretariat of the Investment Partnership Program (PPI). ${ }^{9}$ The PPI works as a ministerial-level executive committee that encompasses all relevant public sector stockholders. As such, it is wellsuited to coordinate the efforts to implement this study's recommendations.

Figure 3 presents the purpose and availability of the mechanisms associated with the recommendations discussed in the previous section. The instruments shaded in green are already operational, those in yellow exist but could be improved and those in orange are scarce and need to be developed further.

Once the government has identified which recommendations to address, an action plan on how to move them forward can be developed based on discussions with the government entities involved. Some recommendations require changes in regulations, while others could be advanced by adapting BNDES and/or government policies. The IDB and the Forum could then support the Brazilian Government in implementing the recommendations.

Figure 3: Status of mechanisms associated with study recommendations

\begin{tabular}{|c|c|c|c|}
\hline & Protection against Construction Risks & Credit During Construction & Credit After Construction \\
\hline \multirow{3}{*}{$\begin{array}{l}\bar{\sigma} \\
\overline{0} \\
\frac{\pi}{0} \\
\frac{0}{0} \\
\frac{0}{0}\end{array}$} & Corporate guarantees & BNDES & BNDES \\
\hline & Bank guarantees & Infrastructure Debentures & Infrastructure Debentures \\
\hline & & Multilateral Development Bank finance & Multilateral Development Bank finance \\
\hline \multirow{3}{*}{ 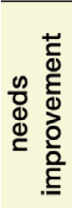 } & Multilateral Development Bank guarantees & $\begin{array}{l}\text { Infrastructure Debentures' } \\
\text { investors base }\end{array}$ & $\begin{array}{l}\text { Infrastructure Debentures' } \\
\text { investors base }\end{array}$ \\
\hline & $\begin{array}{l}\text { Completion bonds } \\
\text { (seguro completion) }\end{array}$ & Mini-Perms & Basel III regulations \\
\hline & & Step-in rights & Step-in rights \\
\hline \multirow{3}{*}{ 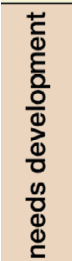 } & Standardize EPC contracts & Financing in USD & Financing in USD \\
\hline & Reserve accounts & $\begin{array}{l}\text { Long-term foreign exchange } \\
\text { rate hedge }\end{array}$ & $\begin{array}{l}\text { Long-term foreign exchange } \\
\text { rate hedge }\end{array}$ \\
\hline & & & BNDES' asset recycling \\
\hline
\end{tabular}

Source: Mellis and Fenolio (2018).

Notes: BNDES = National Bank for Economic and Social Development; EPC = Engineering, Procurement and Construction; USD = US dollars. 


\section{Endnotes}

1. Central Bank of Brazil Resolution \# 2.844 of 29 June 2001.

2. A regulated interest rate set quarterly by the National Monetary Council (composed of the Minister of Finance, who acts as its chairman, the Minister of Planning and the Central Bank Governor) that served as the base interest rate for BNDES loans.

3. Pereira and Puga (2016).

4. Authors' forecast based on BNDES (2017). Please refer to Figure 1 and to Mellis, C. and Fenolio, L. (2018) for details.

5. See Serebrisky et al. (2015).

6. Authors scenarios based on BNDES (2017). Refer to Figure 1 and to Mellis, C. and Fenolio, L. (2018) for details.

7. Ministério da Fazenda (2018) and Mellis, C. and Fenolio, L. (2018).

8. Casa Civil is the Chief of Staff of the Presidency.

9. The Investment Partnerships Program (PPI) was created in 2016 to coordinate public-private partnerships for federal infrastructure investments. It comprises the President of Brazil, government ministers from the ministries concerned, Federal Public Bank Chief Executive Officers, and a dedicated Special Secretariat. 


\section{References}

Banco Nacional de Desenvolvimento Econômico e Social (BNDES). 2017. "Perspectivas do Investimento 2017-2020." Outubro.

Mellis, C., and L. Fenolio. 2018. Melhorando a Financiabilidade da Infraestrutura no Brasil. Unpublished Manuscript.

Ministério da Fazenda. 2018. "Boletim Informativo de Debêntures Incentivadas". 58a edição. Setembro. Available at: http://fazenda.gov.br/centrais-de-conteudos/publicacoes/boletim-de-debentures-incentivadas/arquivos/2018/2018.

Pereira, A. and Puga, F. P. 2016. "Infraestrutura no Brasil: Ajustando o Foco". Novembro. Textos para Discussão 112. Banco de Desenvolvimento Econômico e Social (BNDES). Rio de Janeiro.

Serebrisky, Tomás, Ancor Suárez-Alemán, Diego Margot, and Maria Cecilia Ramirez. 2015. Financing Infrastructure in Latin America and the Caribbean: How, How Much and by Whom? Washington, DC, Inter-American Development Bank. 


\section{Acknowledgements}

To explore tangible ways of accelerating investment in Brazilian infrastructure and to shape the agenda and policy framework, the Inter-American Development Bank (IDB) and the Forum established a Working Group comprising privatesector stakeholders, multilateral development banks and the public sector (Government of Brazil).

In this context, the IDB, through its Infrastructure Department (INE), hired a consultancy that worked under the stewardship of the Working Group. The IDB and the Forum would like to thank the members of the Working Group and consultants Carlos Mellis and Lara Fenolio. The work of the consultants provides the main source of the information and recommendations in this study, which contains only those recommendations considered by the Working Group to be most relevant. The full consultancy report is available upon request to IDB, in Portuguese only, and contains more detailed and in-depth analysis. Marcelo Allain prepared a draft version of this study, which was revised by Andrés Gómez-Peña and Pablo Pereira dos Santos.

We thank Bernardo Guillamon, Manager of the Office of Outreach and Partnerships; Agustin Aguerre, Manager, Infrastructure and Energy Sector; and Miguel Castilla, Manager of the Office of Strategic Planning and Development Effectiveness, all from the IDB, for their support in funding this study.

\section{Working Group Members}

Marcello Allain, Secretary, Coordination for Investment and Partnerships, Investment Partnership Programe (PPI), Ministry of the Presidency, Brazil

Sylvia Coutinho, Country Head, UBS Group Brazil

Rashad Kaldany, Partner, Chief Investment Officer, BlueOrange Capital

Igino de Mattos, Director, Investment Partnership Programe (PPI), Government of Brazil

Vangelis Papakonstantinou, Lead, Infrastructure Initiatives, World Economic Forum

Pablo Pereira dos Santos, Special Adviser, Office of Strategic Planning and Development Effectiveness, Inter-American Development Bank

\section{Members of the World Economic Forum Global Future Council on Long-term Investing, Infrastructure and Development}

Co-chairs

Rashad-Rudolf Kaldany, Partner, Chief Investment Officer, BlueOrange Capital

Alison Tarditi, Chief Investment Officer, Commonwealth Superannuation Corporation

Jagdeep Bachher, Chief Investment Officer, Office of the Chief Investment Officer of the Regents

Sylvia Coutinho, Country Head, UBS Group, Brazil

Alain Ebobisse, Chief Executive Officer, Africa50

Jérôme Jean Haegeli, Head, Investment Strategy, Swiss Reinsurance Company

Scott Kalb, Chief Executive Officer, KLTI Advisors

Younis Khoori, Undersecretary, Ministry of Finance of the United Arab Emirates

Claude Kurzo, Managing Director; Head, Strategy and Business Development, JPMorgan Chase Bank

Josh Lerner, Unit Head, Entrepreneurial Management; Jacob H. Schiff Professor of Investment Banking, Harvard Business School

Hussain Lootah, Director General, Dubai Municipality

Leslie Warren Maasdorp, Vice-President; Chief Financial Officer, New Development Bank (NDB)

Thomas Maier, Independent expert

Melissa J. Ma, Co-Founder and Managing Partner, Asia Alternatives

Matthew McSorley, Senior Vice-President, Project Support Services, Fluor Corporation

Veronica Nyhan Jones, Global Head, Advisory, Infrastructure and Natural Resources, International Finance

Corporation (IFC) 
Pang Yee Ean, Director-General, Investment Operations Department, Asian Infrastructure Investment Bank (AllB) Armando Senra, Head, Latin America and Iberia Region, BlackRock Lutfey Siddiqi, Visiting Professor-in-Practice, London School of Economics and Political Science Ramesh Subramaniam, Director-General, South-East Asia Department, Asian Development Bank Ramesh Subramanyam, Chief Financial Officer, The Tata Power Company Jean-Paul Villain, Director, Strategy Unit, Abu Dhabi Investment Authority Barry White, Chief Executive, Transport for the North Theresa Whitmarsh, Executive Director, Washington State Investment Board Jiao Xiaoping, Director-General, China Public-Private Partnerships Center Robert van Zwieten, Chief Executive Officer, The Serendra Group 


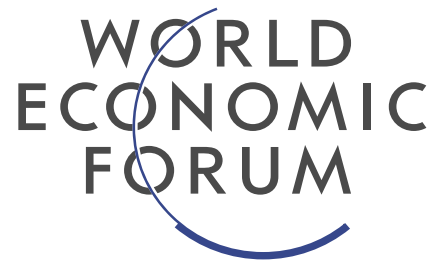

COMMITTED TO

IMPROVING THE STATE

OF THE WORLD

The World Economic Forum, committed to improving

the state of the world, is the International Organization for

Public-Private Cooperation.

The Forum engages the foremost political, business and other leaders of society to shape global, regional and industry agendas. 